\title{
PENINGKATAN KEMAMPUAN GURU DALAM MENYUSUN RPPH MELALUI KEGIATAN SUPERVISI AKADEMIK DAN PENDAMPINGAN DI TK BINAAN PADA SEMESTER 1 TAHUN 2016/2017
}

\author{
Sukarmi
}

Email: sukarmi_bkh@yahoo.co.id

\begin{abstract}
Abstrak
.Tujuan penelitian ini adalah agar para guru dapat mengaplikasikan Rencana Pelaksanaan Pembelajaran Harian (RPPH) sehingga sasaran kurikulum 2013 dapat terealisasikan dengan baik. Penelitian dilaksanakan di TK binaan Kecamatan Wirobrajan dan diikuti sebanyak 20 guru. Metode yang digunakan adalah angket dan wawancara untuk mendapatkan data Peningkatan Kemampuan Guru dalam menyusun rencana pelaksanaan pembelajaran harian di TK binaan. Model penelitian yang digunakan adalah Penelitian Tindakan Sekolah. Penelitian dilaksanakan dalam siklus dan melalui proses pengkajian melalui empat tahap yaitu perencanaan, pelaksanaan, observasi, dan refleksi. Analisis yang digunakan adalah teknik deskriptif kuantitatif. Hasil yang diperoleh dari siklus satu yaitu sesi pemberian materi dan sesi latihan penyusunan rencana cukup sebanyak 16 orang atau $80 \%$ dan dengan hasil baik sebanyak 4 orang atau 20\%. Hasil yang diperoleh dari siklus dua yaitu sesi ketiga pendalaman materi dan sesi keempat pemberian tugas dan evaluasi menunjukkan bahwa peserta yang mencapai hasil cukup sebanyak 4 orang atau $20 \%$ dan dengan hasil baik sebanyak 16 orang atau $80 \%$ pada siklus 3 dan 20 orang dengan hasil baik atau $100 \%$
\end{abstract}

Kata kunci: Peningkatan Kemampuan, Rencana Pelaksanaan Pembelajaran Harian

\section{THE IMPROVEMENT OF TEACHERS'SKILL IN RPPH THROUGH ACADEMIC SUPERVISION AND ITS ASSISTANCE IN TK BINAAN (THE TARGETED KINDERGARTEN) IN THE FIRST SEMESTER OF 2016/2017 ACADEMIC YEAR}

\begin{abstract}
The aim of the study is that teachers apply the Daily Learning Implementation Plan so that the goals of the 2013 curriculum can be realized well. The research was conducted in kindergarten at Wirobrajan sub-district and followed by 20 teachers. The methods used were questionnaires and interviews to obtain data on Teacher Capacity Improvement in preparing the daily implementation plan learning in the kindergarten. The research model used was school action research. The research was carried out in the cycle and through the process of assessment through using stages: (1) planning, (2) implementation, (3) observation, and (4) reflection. The analysis used was quantitative descriptive technique. The results in the first cycle related to the material delivery sessions and training of planning session were as many as 16 people or $80 \%$ and with good results as much as 4 people or $20 \%$. The results the second cycle which were the third session of material deepening and the fourth session of assignment and evaluation showed that the participants achieved enough result were as much as 4 people or $20 \%$ and with good result as much as 16 people or $80 \%$ in cycle three and 20 people with good results or $100 \%$.
\end{abstract}

Keywords: Skills Improvement, Daily Learning Implementation Plan

\section{PENDAHULUAN}

Kondisi nyata di sekolah binaan setelah dilakukan supervisi masih banyak guru yang dalam menyusun Rencana Pelaksanaan Pembelajaran Harian (RPPH) belum maksimal dalam pembuatannya. 
Hal tersebut dikarenakan Kepala sekolah dan guru belum secara keseluruhan menerima pelatihan tentang kurikulum 2013. Di Taman Kanak Kanak Kurikulum 2013 baru serentak dilaksanakan pada semester I tahun pelajaran 2016/2017. Tentu saja merupakan masa transisi dari penggunaan Kurikulum terdahulu menuju Kurikulum 2013. Pengawas sangat menyadari dengan keadaan ini. Oleh karena itu pengawas mencoba mengetahui sejauh mana penguasaan kemampuan guru dalam menyusun rencana pelaksanaan pembelajaran harian atau rencana kegiatan harian melalui supervisi akademik dan pendampingan.

Penyusunan rencana pelaksanaan pembelajaran harian atau rencana kegiatan harian merupakan salah satu indikator dalam penyusunan laporan sasaran kinerja pegawai bagi PNS Hal tersebut sesuai dengan Peraturan Pemerintah Nomor 46 Tahun 2011 tentang Penilaian Prestasi Kerja Pegawai Negeri Sipil PNS. Di dalam peraturan pemerintah tersebut disebutkan bahwa prestasi kerja PNS akan dinilai berdasarkan 2 (dua) unsur penilaian, yaitu SKP (sasaran kerja pegawai) yang meliputi rencana kerja dan target yang akan dicapai oleh seorang PNS dan perilaku kerja yang meliputi setiap tingkah laku, sikap, tindakan yang dilakukan oleh PNS yang harus sesuai dengan ketentuan undang undang.

Guru TK (PNS) sebagai tenaga pendidik secara langsung harus melaksanakan ketentuan yang berlaku dalam PP tersebut. Salah satu indikatornya adalah dengan melaksanakan tugas pokok guru TK yakni melaksanakan SKP diantaranya terdiri dari (1) penyusunan program tahunan, (2) menyusun program semester, (3) menyusun rencana kegiatan mingguan, atau rencana pelaksanaan mingguan, (4) rencana pelaksanaan pembelajaran harian atau rencana kegiatan harian, (5) melaksanakan pembelajaran, (6) melaksanakan penilaian, menganalisis hasil penilaian.
Berdasarkan kondisi ideal dan kondisi nyata tersebut terdapat kesenjangan:

1. Guru dituntut untuk menyusun rencana pelaksanaan pembelajaran harian tetapi dalam kenyataannya guru belum semua guru mampu menyusun rencana pelaksanaan pembelajaran harian tersebut.

2. Untuk mampu menyusun rencana pelaksanaan pembelajaran harian, guru haruslah mendapatkan diklat secara keselurahan terlebih dahulu, tetapi dalam kenyataannya, diklat dari tim penyusun kurikulum belum menyeluruh

3. Untuk menyusun rencana pelaksanaan pembelajaran harian, namun dalam kenyataannya belum semua TK memiliki buku panduan tersebut karena kalau ada pada kepala sekolahbelum di perbanyak

4. Kemampuan kepala sekolah untuk melakukan pembimbingan langsung juga belum berani karena merasa belum memahami seutuhnya tentang bagaimana menyusun rencana pelaksanaan pembelajaran sesuai kurikulum 2013 PAUD

Untuk mengatasi hal tersebut, pengawas sekolah sesuai tanggung jawabnya memiliki peluang untuk mengatasi masalah ini dengan menggunakan kewenangannya, yakni melakukan supervisi akademik dan pendampingan. Melalui supervisi akademik, seorang pengawas memiliki wewenang untuk menilai dan membina guru dalam rangka meningkatkan kualitas proses pembelajaran yang pada gilirannya akan berdampak pada peningkatan kualitas siswa. Supervisi akademik adalah serangkaian kegiatan yang membantu pendidik mengembangkan kemampuannya untuk mengelola proses pembelajaran sehingga tujuan pembelajaran dapat tercapai. Kegiatan supervisi akademik dapat difokuskan pada pembinaan guru sesuai dengan kondisi sehingga pada gilirannya mereka dapat mengelola proses pembelajaran. 
Salah satu tugas guru adalah menyusun rencana pelaksanaan pembelajaran harian. Penyusunan ini dimaksudkan agar proses pembelajaran dapat dilaksanakan lebih terstruktur, terperinci, runut dan sesuai dengan kurikulum dan ketentuan-ketentuan pembelajaran yang sudah disusun oleh pemerintah. Dengan penyusunan rencana pelaksanaan pembelajaran harian, materi yang disampaikan kepada anak didik dapat teraplikasikan dengan baik. Melalui supervisi akademik, seorang pengawas dapat membantu guru untuk menyusun rencana pelaksanaan pembelajaran harian. Seperti disebutkan di atas, akibat kurangnya diklat dan pengetahuan guru mengenai kurikulum 2013, guru tidak dapat menyusun rencana pelaksanaan pembelajaran harian sesuai dengan kurikulum yang berlaku. Untuk itulah, pengawas memiliki peran untuk membimbing dan membina guru agar dapat menyusun rencana pelaksanaan pembelajaran harian yang pada gilirannya dapat diaplikasikan dalam proses pembelajaran. Melalui supervisi akademik oleh pengawas sekolah diharapkan tujuan kurikulum 2013 khususnya dalam penyusunan pelaksanaan pembelajaran harian dapat tercapai. Sasarannya adalah (1) agar setiap guru mempunyai kesadaran yang tinggi dalam menyusun rencana pelaksanaan pembelajaran harian, (2) guru dapat menerapkan dan mengaplikasikan materi dalam menyusun rencana pelaksanaan pembelajaran harian dalam proses pembelajaran.

Identifikasi masalah penelitian ini antara lain: 1) Belum semua guru memperoleh diklat secara langsung oleh tim penyusun Kurikulum; 2) Kompetensi guru menyusun rencana pelaksanaan pembelajaran masih kegiatan harian iklim kerja yang kurang kompetitif, artinya guru terbiasa cukup dengan apa adanya. Hal ini karena lemahnya kepala sekolah dalam melaksanakan supervisi akademik dan faktor kemampuan guru dalam memahami tugasnya.
Pembatasan masalah penelitian ini yaitu meningkatkan kemampuan guru dalam menyusun rencana pelaksanaan pembelajaran harian melalui supervisi akademik dan pendampingan di TK binaan.

Rumusan masalah penelitian ini yaitu Apakah melalui supervisi akademik dan pendampingan dapat meningkatkan kemampuan guru dalam menyusun rencana pelaksanaan pembelajaran harian di TK binaan.

Tujuan penelitian ini meningkatkan kemampuan guru dalam Menyusun Rencana Pelaksanaan Pembelajaran Harian mengaplikasikan rencana kegiatan harian sehingga sasaran kurikulum tersebut dapat terealisasikan dengan baik.

Manfaat teoritis penelitian ini antara lain: 1) Pemahaman guru TK dalam menyusun rencana pelaksanaan pembelajaran harian menjadi lebih paham setelah diterapkan supervisi akademik dan pendampingan di TK Binaan pada Semester 1; 2) Keterampilan guru TK dalam menyusun rencana pelaksanaan pembelajaran harian semakin meningkat setelah diterapkan supervisi akademik dan pendampingan di TK Binaan pada Semester 1 tahun 2016/20167; 3) Mengubah sikap guru TK dalam menyusun rencana pelaksanaan pembelajaran harian setelah dilaksanakan supervisi akademik dan pendampingan di TK Binaan pada semester 1 Tahun 2016/2017.

Manfaat praktis penelitian ini bagi kepala sekolah dan guru, diharapkan sebagai umpan balik untuk melakukan peningkatan kinerja proses pembelajaran. Bagi kepala sekolah dan pengawas, penelitian ini dapat dijadikan sebagai masukan dan alternatif peningkatan kinerja proses pembelajaran guru dengan menerapkan supervisi dan pendampingan. Sementara itu, bagi siswa penelitian ini diharapkan dapat memberikan suasana pembelajaran yang lebih menyenangkan dan menarik. 


\section{Pengertian Peningkatan}

Peningkatan berasal dari kata dasar tingkat yang berarti lapis atau lapisan dan sesuatu yang kemudian akan membentuk susunan. Tingkat juga berarti pangkat, taraf, dan kelas. Peningkatan merupakan proses perubahan untuk meningkatkan sesuatu dengan usaha. Peningkatan mengacu kepada sesuatu yang naik atau lebih maju. Secara umum peningkatan merupakan upaya untuk menambah derajat tingkat kualitas maupun kuantitas, peningkatan juga berarti perubahan keterampilan dan kemampuan agar menjadi lebih baik. Selain itu juga peningkatan juga berarti pencapaian dalam proses ukuran, sifat, hubungan dan sebagainya. Kata peningkatan juga dapat menggambarkan perubahan dari keadaan atau sifat yang negatif berubah menjadi positif sedangkan hasil dari sebuah peningkatan dapat berupa kualitas.

Dengan demikian, peningkatan berarti menaikkan derajat sesuatu atau seseorang serta dapat pula berarti mempertinggikan, memperhebat. Dari pengertian tersebut dapat disimpulkan bahwa peningkatan adalah usaha memecahkan masalah dan mencari jalan keluar untuk meningkatkan hasil dari suatu kegiatan.

\section{Pengertian Kemampuan}

Robbin (2007:57) mendefinisikan kemampuan sebagai "kapasitas seseorang individu untuk melakukan beragam tugas dalam suatu pekerjaan". Lebih lanjut Robbin menyatakan bahwa "kemampuan (ability) adalah sebuah penilaian terkini atas apa yang dapat dilakukan seseorang". Robbin mengartikan bahwa kemampuan merupakan sebuah kapasitas yang dimiliki oleh tiap-tiap individu untuk melaksanakan tugasnya, sehingga dapat diambil kesimpulan bahwa kemampuan merupakan suatu penilaian atau ukuran dari apa yang dilakukan orang tersebut.

Kemampuan juga dapat berarti sebagai keefektifan seseorang dalam melakukan segala macam pekerjaan, yang artinya kemampuan merupakan dasar dari seseorang tersebut dalam melakukan sebuah pekerjaan secara efektif dan efisien. Dari pengertian tersebut dapat disimpulkan bahwa kemampuan merupakan kecakapan setiap individu untuk menyelesaiakan pekerjaanya atau menguasai hal-hal yang ingin dikerjakan dalam suatu pekerjaan dan dapat dilihat dari tiap-tiap individu, sedangkan kemampuan itu dibagi menjadi beberapa kelompok yaitu kelompok kemampuan intelektual dan kelompok kemampuan fisik. Kemampuan intelektual yaitu kemampuan yang dimiliki seseorang waktu melakukan aktifitas yang membentuk kemampuan berfikir sedangkan kemampuan fisik merupakan kemampuan melakukan tugas-tugas yang menuntut tenaga atau stamina dengan ketrampilan kekuatan atau karakteristik serupa.

\section{Rencana Pelaksanaan Pembelajaran Harian}

Rencana Pelaksanaan Pembelajaran Harian merupakan penjabaran dari rencana Pelaksanan Pembelajaran Mingguan. RKH berisi kegiatan yang akan dilaksanakan setiap harinya di sekolah. Rencana Pelaksanaan Pembelajaran Harian disusun dengan target-target capaian tertentu, dari mulai hari, minggu, bulan, semster, dan tahun. Adapun Rencana Pelaksanaan Pembelajaran Harian memuat kegiatan-kegiatan pembelajaran baik yang dilaksanakan secara individual, kelompok, maupun klasikal dalam satu hari. Rencana Pelaksanaan Pembelajaran Harian terdiri atas kegiatan pembukaan, kegiatan isi, istirahat, dan kegiatan penutup.

Rencana pelaksanaan pembelajaran harian dapat dikembangkan dalam model pembelajaran kelompok dengan kegiatan pengamatan dan rencana pelaksanaan pembelajaran harian model pembelajaran berdasarkan minat. Rencana pelaksanaan pembelajaran harian model pembelajaran berdasarkan minat sendiri dapat dikembangkan melalui tiga model, yaitu : rencana pelaksanaan pembelajaran harian model 
pembelajaran berdasarkan sudut-sudut kegiatan, rencana pelaksanaan pembelajaran harian model pembelajaran area, dan rencana pelaksanaan pembelajaran harian model pembelajaran sentra.

Tabel 1. Komponen RKH terdiri dari:

\begin{tabular}{|c|c|c|}
\hline No & ASPEK & KOMPONEN RPP \\
\hline 1 & $\begin{array}{l}\text { Identitas } \\
\text { Program }\end{array}$ & $\begin{array}{l}\text { 1. Terdapat identitas lembaga yang menyusun RPPH } \\
\text { 2. Terdapat Semester,bulan,Minggu } \\
\text { 3. Terdapat hari dan tanggal } \\
\text { 4. Tema/Sub tema/sub - subtema diambil dari tema/subtema yang disusun } \\
\text { diprogram semester } \\
\text { 5. Kelompok usia anak didik sesuai dengan kelompok sasaran }\end{array}$ \\
\hline 2 & Materi & $\begin{array}{l}\text { 1. Materi diambil dari materi yang telah dijabarkan di RPPM } \\
\text { 2. Materi sejalan dengan tujuan yang telah ditulis } \\
\text { 3. Materi untuk pengembangan sikap dapat ditulis di RPPH lalu masuk ke } \\
\text { SOP atau langsung dimasukkan menjadi kegiatan rutin dan diterapkan } \\
\text { melalui pembiasaan serta diulang-ulang setiap hari sepanjang tahun } \\
\text { 4. Materi pengembangan pengetahuan dan ketrampilan dikenalkan sesuai } \\
\text { dengan RPPH }\end{array}$ \\
\hline 3 & $\begin{array}{l}\text { Alat dan } \\
\text { Bahan }\end{array}$ & $\begin{array}{l}\text { 1. Alat dan bahan sangat terkait dengan kegiatan yang akan dikelola guru } \\
\text { pada hari itu } \\
\text { 2. Kegiatan diambil dari beberapa rencana kegiatan yang ada di RPPM } \\
\text { 3. Kegiatan yang ditetapkan tergantung pada pengelolaan model } \\
\text { pendekatan yang digunakan } \\
\text { 4. Alat dan bahan disiapkan yang menarik minat belajar anak }\end{array}$ \\
\hline 4 & $\begin{array}{l}\text { Kegiatan } \\
\text { Pembukaan }\end{array}$ & $\begin{array}{l}\text { 1. Kegiatan Pembukaan ditujukan untuk membantu membangun minat } \\
\text { anak agar anak siap bermain di kegiatan inti } \\
\text { 2. Kegiatan pembukaan untuk mengenalkan materi pembelajaran } \\
\text { 3. Kegiatan pembukaan dimanfaatkan guru untuk mengenalkan kegiatan } \\
\text { bermain yang sudah disiapkan, aturan bermain,menerapkan } \\
\text { pembiasaan- pembiasaan dsb }\end{array}$ \\
\hline 5 & Kegiatan Inti & $\begin{array}{l}\text { 1. Proses belajar menerapkan pendekatan saintifik } \\
\text { 2. Proses pembelajaran dengan menggunakan pendekatan scientific } \\
\text { diterapkan secara fleksibel dan lebih luas } \\
\text { 3. Kegiatan inti memberi keleluasaan kepada anak untuk bereksplorasi, } \\
\text { membangun pengalaman bermain yang bermakna } \\
\text { 4. Pada tahap mengomunikasikan ditekankan pada anak menyampaikan } \\
\text { gagasannnya melalui berbagai kegiatan bermain } \\
\text { 5. Kegiatan bermain disesuaikan dengan model pembejaran } \\
\text { 6. Jumlah kegiatan yang disediakan setiap harinya minimal } 4 \text { kegiatan yang } \\
\text { berbeda untuk memfasilitasi anak agar tetap fokus bermain } \\
\text { 7. Penguatan mengingat atau recalling merupakan bagian dari kegiatan inti }\end{array}$ \\
\hline 6 & $\begin{array}{l}\text { Kegiatan } \\
\text { Penutup }\end{array}$ & $\begin{array}{l}\text { 1. Kegiatan penutup dilakukan diakhir kegiatan } \\
\text { 2. Kegitan Penutup berupa transisi dari sekolah ke rumah } \\
\text { 3. Kegiatan penutup dapat mengulang kembali apa yang dilakukan saat } \\
\text { kegiatan pembukaan } \\
\text { 4. Kegiatan penutup dapat diisi dengan kegiatan rutin untuk memperkuat } \\
\text { kegiatan yang diharapkan } \\
\text { 5. Kegiatan penutup dilakukan untuk menarik minat anak belajar esok } \\
\text { harinya }\end{array}$ \\
\hline 7 & $\begin{array}{l}\text { Rencana } \\
\text { Penilaian }\end{array}$ & $\begin{array}{l}\text { 1. Indikator perkembangan mengacu pada indikato r yang tertuang pada } \\
\text { lampiran Permendikbud } 146 \text { tahun } 2014 \text { tentang Kurikulum } 2013 \\
\text { PAUD } \\
\text { 2. Indikator Penilaian disesuaikan dengan tujuan pembelajaran dan materi } \\
\text { pembelajaran } \\
\text { 3. Indikator penilaian sudah dikelompokkan kedalam program } \\
\text { pengembangan untuk memudahkan dalam penyusunan laporan } \\
\text { 4. Terdapat Format rencana penilaian }\end{array}$ \\
\hline
\end{tabular}




\section{Pengertian Supervisi}

Pengertian supervisi menurut Ngalim Purwanto dalam Administrasi dan Supervisi Pendidikan (1995:76) supervisi ialah aktivitas pembinaan yang direncanakan untuk membantu para guru dan pegawai sekolah lainnya dalam melakukan pekerjaan mereka secara efektif.

Pembinaan dalam penelitian akan membahas pembinaan yang dilakukan oleh pengawas sekolah di TK Binaannya. Menurut keputusan menteri negara pendayagunaan aparatur negara nomor 118/1996 tentang Jabatan Fungsional Pengawas Sekolah dan angka Kreditnya bab I pasal 1 pengawas sekolah adalah pegawai negeri sipil yang diberi tugas, tanggung jawab dan wewenang secara penuh oleh pejabat yang berwenang untuk melakukan pengawasan pendidikan di sekolah dengan melaksanakan penilaian dan pembinaan dari segi teknis pendidikan dan administrasi pada satuan pendidikan pra sekolah, dasar dan menengah.

Supervisi pengajaran disebut juga supervisi akademik. Menurut Purwanto (1995), supervisi pengajaran ialah kegiatan-kegiatan kepengawasan yang ditujukan untuk memperbaiki kondisikondisi baik personel maupun material yang memungkinkan terciptanya situasi belajar mengajar yang lebih baik dan terciptanya tujuan pendidikan. Supervisi akademik biasanya dilaksanakan oleh Kepala Sekolah atau Pengawas Sekolah. Pengawas sekolah mengamati dari persiapan mengajarnya (RPP) sampai proses pembelajarannya dengan tujuan untuk peningkatan mutu PBM. Kompetensi supervisi akademik intinya adalah membina guru dalam meningkatkan mutu proses pembelajaran. Oleh sebab itu sasaran supervisi akademik adalah guru dalam proses pembelajaran, yang terdiri dari materi pokok dalam proses pembelajaran, penyusunan silabus dan RPP, pemilihan strategi/metode/teknik pembelajaran, penggunaan media dan teknologi informasi dalam pembelajaran, menilai proses dan hasil pembelajaran serta penelitian.

Keterampilan utama dari seorang pengawas adalah melakukan penilaian dan pembinaan kepada guru untuk secara terus menerus meningkatkan kualitas proses pembelajaran yang dilaksanakan di kelas agar berdampak pada kualitas hasil belajar siswa. Dari pengertian supervisi akademik di atas dapat disimpulkan bahwa supervisi akademik adalah kegiatan pembinaan yang dilakukan oleh kepala sekolah/pengawas sekolah kepada guru untuk membantu memecahkan masalah yang berhubungan dengan proses pembelajaran agar mutu/kualitas pembelajaran bisa maksimal. Supervisi akademik bisa berupa supervisi perencanaan pembelajaran dan supervisi pelaksanaan pembelajaran

Kelebihan atau kekuatan supervisi akademik adalah mampu mengarahkan proses pembelajaran secara terarah dan sistematik sesuai dengan kebutuhan guru. Supervisi akademik menjadikan penyusunan program dapat dilakukan lebih baik karena adanya pendampingan dari para pengawas. Selain itu, supervisi akademik juga dapat menjadi media penilaian sekaligus evaluasi hasil kegiatan yang telah dijalankan. Dengan adanya supervisi akademik, perencanaan pembelajaran dan pelaksanaan pembelajaran dapat berjalan secara siginifan dan saling bersinergi untuk mengurai setiap permaslahan yang dihadapi para guru.

Supervisi Akademik

Supervisi akademik adalah serangkaian kegiatan membantu pendidik mengembangkan kemampuannya dalam mengelola proses pembelajaran untuk mencapai tujuan pembelajaran. Supervisi akademik bukan penilaian unjuk kerja pendidik melainkan membantu pendidik mengembangkan kemampuan profesionalismenya.

Supervisi akademik kaitannya dengan tugas pengawas sekolah adalah berkenaan dengan aspek pelaksanaan tugas 
pembinaan, pemantauan dan penilaian kinerja guru dalam perencanaan, pelaksanaan, penilaian hasil pembelajaran dan pembimbingan serta pelatihan peserta didik.

Kegiatan supervisi akademik ini fokus pada pembinaan guru sesuai kondisi sebenarnya di sekolah tentang kemampuan pendidik dalam mengelola proses pembelajaran peserta didik. Selanjutnya pemantauan fokus pada standar isi, standar kompetensi lulusan, standar proses, dan standar penilaian. Pengawas sekolah sebagai supervisor dapat mengembangkan supervisi akademik dengan memberikan motivasi dan memberikan pelayanan supervisi akademik secara optimal kepada para pendidik sesuai kondisi pendidik yang ada di sekolah. Dari kegiatan ini diharapkan terjadi perubahan perilaku pendidik ke arah yang lebih berkualitas dan akan menimbulkan perilaku belajar peserta didik menjadi lebih baik. Proses pembelajaran yang berkualitas dan hasil belajar peserta didik yang baik merupakan satu indikator keberhasilan kinerja Pengawas Sekolah. Untuk itu Pengawas Sekolah perlu mengembangkan supervisi akademik melalui denga membuat perencanaan, pelaksanaan, dan evaluasi serta tindak lanjut supervisi akademik.

\section{Kerangka Berpikir}

Peningkatan kemampuan menyusun rencana kegiatan harian mempunyai arti yang sangat penting bagi ketugasan seorang guru, hal itu tidak terlepas dari salah satu tugas guru, sehingga merupakan hal yang mendesak untuk segera dilaksanakan.
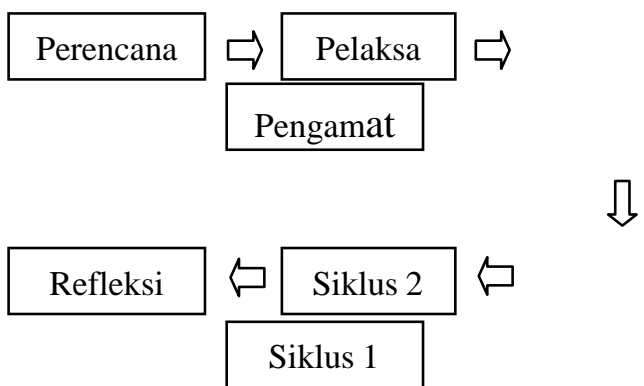

Gambar 1. Kerangka Berpikir

\section{Hipotesis Tindakan}

Melalui supervise supervisi akademik dan pendampingan dapat meningkatkan kemampuan guru dan kepala TK pada TK binaan dalam menyusun Rencana Pelaksanaan Pembelajaran Harian.

\section{METODE PENELITIAN}

Penelitian ini menggunakan metode kuantitatif, yakni metode penelitian ilmiah yang sistematis terhadap bagian-bagian dan fenomena serta hubungan-hubungannya. Tujuan penelitian kuantitatif adalah mengembangkan dan menggunakan model-model matematis, teori-teori, dan/atau hipotesis yang saling berkaitan. Proses pengukuran adalah bagian yang sentral dalam penelitian kuantitatif karena hal ini memberikan hubungan yang fundamental antara pengamatan empiris dan ekspresi matematis dari hubungan-hubungan kuantitatif.

Penelitian kuantitatif banyak dipergunakan baik dalam ilmu-ilmu alam maupun ilmu-ilmu sosial, dari fisika dan biologi hingga sosiologi dan jurnalisme. Pendekatan ini juga digunakan sebagai cara untuk meneliti berbagai aspek dari pendidikan. Istilah penelitian kuantitatif sering dipergunakan dalam ilmu-ilmu sosial untuk membedakannya dengan penelitian kualitatif.

Penelitian kuantitatif adalah definisi, pengukuran data kuantitatif dan statistik objektif melalui perhitungan ilmiah berasal dari sampel orang-orang atau penduduk yang diminta menjawab atas sejumlah pertanyaan tentang survei untuk menentukan frekuensi dan persentase tanggapan mereka. Sebagai contoh: 240 orang, $79 \%$ dari populasi sampel, mengatakan bahwa mereka lebih percaya pada diri mereka pribadi masa depan mereka dari setahun yang lalu hingga hari ini. Menurut ketentuan ukuran sampel statistik yang berlaku, maka $79 \%$ dari penemuan dapat diproyeksikan ke seluruh populasi dari sampel yang telah dipilih. Pengambilan data ini disebut sebagai 
survei kuantitatif atau penelitian kuantitatif.

Tempat penelitian ini di TK binaan

Waktu pelaksanaan penelitian ini pada bulan Oktober 2016 di wilayah Kecamatan Wirobrajan.

Tabel 2. Objek Penelitian

\begin{tabular}{lll}
\hline NO & NAMA TK & KEADAAN GURU \\
\hline 1 & TK ABA Singosaren & Siti Fathonah \\
& & Tri Mulianingsih \\
2 & TK ABA Kuncen II & Istinah \\
3 & TK ISLAM Al Haq & Ris Pratiwi \\
& & Santi Ednawati \\
& & Hanifah \\
4 & TK Bopkri Wirobrajan & sri supartinah \\
& & Anton Parjuni \\
& & Tutik \\
& & Dyah Widisih \\
4 & TK ABA Patang Puluhan & Titi Lestari \\
& & Ema Orbandari \\
& & Ispurwanti \\
& TK Kartini Patang Puluhan & Sri Isnaini \\
& & Tumini \\
5 & TK ABA Tegalmulyo & Sri Cahyaningsih \\
& & Siti Maslikhah \\
6 & TK ABA Wirobrajan I & Iskamtiyati \\
& & Ngatirah \\
& & Ani Rubia Bekti \\
\hline
\end{tabular}

\section{Data dan Sumber Data}

1. Berdasarkan sumber perolehannya Berdasarkan sumber perolehannya, data untuk penelitian ini ada dua macam, yaitu data primer dan data sekunder.

2. Berdasarkan bentuknya

Berdasarkan bentuknya, data untuk penelitian ini juga ada dua macam, yaitu data kualitatif dan data kuantitatif.

3. Berdasarkan waktu pemerolehannya Berdasarkan waktu perolehan data ada dua macam yaitu: data kondisi awal dan data per siklus

\section{Teknik dan Alat Pengumpulan Data}

Berisi cara mengumpulkan data melalui pengamatan langsung atau oleh orang lain, serta instrumen pengamatan yang dapat digunakan untuk mengumpulkan data, yaitu:

1. Observasi

Observasi dapat dilakukan dengan dua cara yaitu :

a. Observasi non sistematis yang dilakukan oleh pengamat dengan tidak menggunakan instrumen pengamatan.
Hal ini dilakukan melalui komunikasi dan melihat kegiatan pembelajaran yang sedang berlangsung di TK subjek penelitian.

b. Observasi sistematis yang dilakukan oleh pengamatan dengan menggunakan pedoman sebagai pengamatan. Hal ini dilakukan dengan melihat Rencana Pelaksanaan Pembelajaran Harian yang dijalankan di TK subjek penelitian.

2. Pendampingan

Pendampingan adalah sebuah kegiatan yang dilakukan untuk menyampaikan materi yang dibutuhkan dan memastikan bahwa peserta memahami dan dapat menyusun materi berupa rencana kegiatan harian. Hal ini dilakukan melalui sesi pemberian materi dan tanya jawab.

Pendampingan dilaksanakan dalam 2 siklus melalui pertemuan yang terjadwal yaitu 1 minggu sekali selama 1 bulan (4 sesi). Sebelumnya dilakukan pengamatan awal mengenai 
Rencana Pelaksanaan Pembelajaran Harian yang digunakan apakan sudah terdapat aspek yang terdapat pada petunjuk. Siklus satu yaitu sesi pertama difokuskan dalam penyampaian materi dan sesi kedua latihan penyusunan rencana kegiatan harian dan tanya jawab. Siklus dua yaitu sesi ketiga pendalaman materi dan sesi keempat pemberian tugas dan evaluasi.

Peneliti memberikan tugas untuk mengukur sejauh mana guru dan kepala sekolah memahami materi dan dapat menyusun serta mengaplikasikan rencana rencana pelaksanaan pembelajaran harian.

\section{Validasi Data}

Untuk mengukur validitas penelitian tindakan diperlukan lima kriteria validitas (Gey Anderson dan Katheryn Herr) yakni: validitas hasil (apakah penelitian dapat memecahkan masalah), validitas proses (apakah proses penelitian sesuai kaidah penelitian ilmiah dengan langkah rinci, trianggulasi data), validitas demokratik (apakah pendapat individu diperhatikan), validitas katalistik (apakah penelitian bermanfaat bagi subjek penelitian) dan validitas dialogis (apakah hasil penelitian dievaluasi oleh teman sejawat).

Validasi data penelitian tindakan biasanya menerapkan triangulation of data collection method (metode triangulasi data), yaitu penggunaan lebih dari satu teknik pengambilan data dan menggunakan lebih dari satu pengamat pada saat tindakan demi mendapatkan data yang valid dan menyeluruh.

\section{Teknik Analisis Data}

Prosedur analisis data adalah (1) menyeleksi dan mengelompokkan data sesuai rumusan masalah, (2) mengolah dan mendiskripsikan data agar bermakna dalam bentuk narasi, grafik, maupun tabel dan

Prosedur analisis data adalah (1) menyeleksi dan mengelompokkan data sesuai rumusan masalah, (2) mengolah dan mendiskripsikan data agar bermakna dalam bentuk narasi, grafik, maupun tabel dan (3) menyimpulkan dalam pernyataan singkat dan bermakna sesuai kriteria/indikator kinerja yang telah ditentukan.

\section{HASIL PENELITIAN DAN PEMBAHSAN \\ Hasil Penelitian \\ Pengamatan Awal}

Pengamatan dilakukan dengan menggunakan instrumen pengamatan melalui komunikasi dan melihat kegiatan pembelajaran yang sedang berlangsung di TK objek penelitian serta melihat kurikulum yang dijalankan di TK tersebut. Hasil pengamatan menunjukkan bahwa semua TK objek penelitian belum melaksanakan penyusunan rencana pelaksanaan pembelajaran harian. Hal ini sesuai dengan hipotesa awal bahwa penyusunan rencana pelaksanaan pembelajaran harian belum diterapkan dalam kegiatan pembelajaran harian.

\section{Pelaksanaan Pendampingan}

Siklus 1

Sesi 1 pemberian materi

Materi yang disampaikan
a) Aspek-aspek rencana pelaksanaan pembelajaran harian
b) Langkah penyusunan rencana pelaksanaan pembelajaran harian
c) Penyusunan
d) Penyusunan rencana pelaksanaan pembelajaran harian 


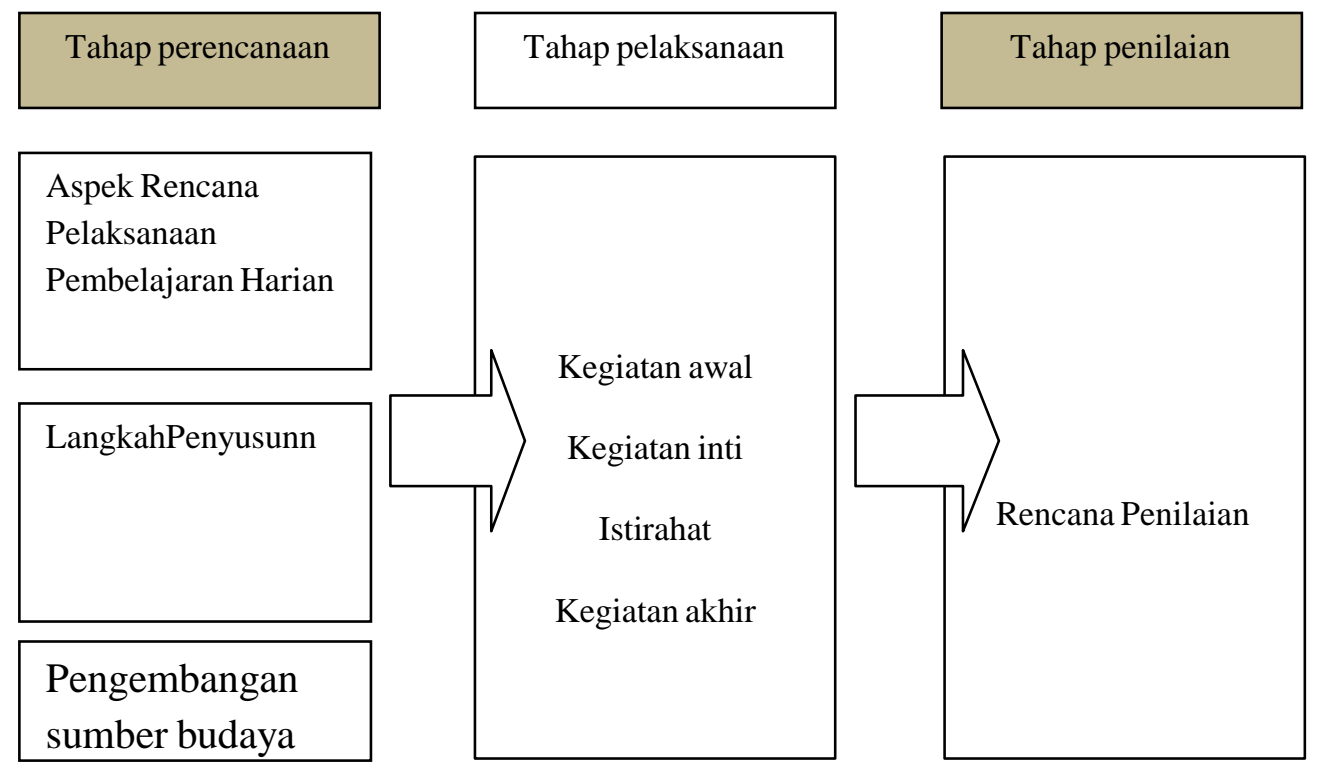

Gambar 2. Penyusunan Rencana Pelaksanaan Pembelajaran Harian

Gambar tersebut di atas adalah bagan dari proses pembelajaran yang diharapkan dapat dilaksanakan setelah guru dan kepala TK memahami penyusunan penyusunan rencana pelaksanaan pembelajaran harian. Adapun pembimbingan mengenai penyusunan rencana kegiatan harian berbasis budaya masuk dalam tahap perencanaan. Hal ini menunjukkan pentingnya guru dan kepala TK mengetahui dan memahami mengenai penyusunan rencana kegiatan harian berbasis penyusunan rencana pelaksanaan pembelajaran harian karena sangat berpengaruh terhadap pelaksanaan proses pembelajaran.
Sesi 2 latihan penyusunan penyusunan rencana pelaksanaan pembelajaran harian dan tanya jawab

Peneliti melakukan latihan penyusunan rencana kegiatan harian dan tanya jawab dengan kepala TK dan guru penyusunan rencana pelaksanaan pembelajaran. Adapun latihan dilakukan melalui diskusi dan pembuatan konsep disertai sesi tanya jawab.

Peneliti mengklasifikasikan peserta yang sudah memahami dan mampu menyusun konsep serta peserta yang masih mengalami kendala dalam pemahaman mengenai materi yang disampaikan. Adapun hasil pengamatan dapat dilihat dalam tabel berikut.

Tabel 3. Hasil penilaian pemberian materi Penyusunan Rencana Pelaksanaan Pembelajaran Harian tahap I

\begin{tabular}{llccccccc}
\hline No & \multicolumn{1}{c}{ Nama } & $\begin{array}{l}\text { Identitas } \\
\text { Program }\end{array}$ & Materi & $\begin{array}{l}\text { Alat } \\
\text { dan } \\
\text { Bahan }\end{array}$ & $\begin{array}{l}\text { Kegiatan } \\
\text { Pembukaan }\end{array}$ & $\begin{array}{l}\text { Kegiatan } \\
\text { Inti }\end{array}$ & $\begin{array}{l}\text { Kegiatan } \\
\text { Penutup }\end{array}$ & $\begin{array}{l}\text { Rencana } \\
\text { Penilaian }\end{array}$ \\
\hline 1 & Siti Fathonah & 70 & 69 & 69 & 58 & 50 & 65 & 63 \\
2 & Tri Mulianingsih & 55 & 69 & 50 & 59 & 57 & 65 & 69 \\
3 & Istinah & 70 & 69 & 50 & 67 & 54 & 75 & 56 \\
4 & Ris Pratiwi & 75 & 75 & 75 & 75 & 75 & 75 & 75 \\
5 & Santi Ednawati & 65 & 75 & 56 & 58 & 75 & 75 & 75 \\
6 & Hanifah & 75 & 75 & 69 & 67 & 75 & 50 & 50 \\
7 & Sri Supartinah & 75 & 75 & 88 & 83 & 75 & 75 & 50 \\
8 & Anton Parjuni & 75 & 75 & 75 & 75 & 79 & 70 & 56 \\
9 & Tutik & 75 & 75 & 75 & 75 & 71 & 55 & 44
\end{tabular}




\begin{tabular}{lllllllll}
10 & Tumpuk & 75 & 75 & 56 & 58 & 75 & 65 & 60 \\
11 & Muji L & 60 & 50 & 50 & 67 & 75 & 75 & 63 \\
12 & Okta & 75 & 75 & 69 & 75 & 68 & 60 & 56 \\
13 & Sumiyatun & 75 & 75 & 75 & 75 & 68 & 55 & 25 \\
14 & Trina & 75 & 69 & 75 & 75 & 68 & 40 & 63 \\
15 & Tumini & 65 & 50 & 75 & 58 & 68 & 65 & 50 \\
16 & Surti Darti & 75 & 69 & 75 & 67 & 64 & 70 & 44 \\
17 & Siti Maslikhah & 75 & 75 & 69 & 67 & 54 & 45 & 44 \\
18 & Iskamtiyati & 75 & 75 & 75 & 67 & 50 & 60 & 50 \\
19 & Ngatirah & 70 & 75 & 75 & 75 & 71 & 55 & 63 \\
20 & Ani Rubia Bekti & 75 & 75 & 75 & 58 & 68 & 75 & 25 \\
\hline
\end{tabular}

Skor maksimal

Ketercapaian: $86 \%-100 \%$

$70 \%-85 \%$

$55 \%-69 \%$

Dibawah $55 \%$
: Sangat baik

: Baik

: Cukup

: kurang
Hasil yang diperoleh dari siklus satu yaitu sesi pemberian materi dan sesi latihan penyusunan rencana kegiatan harian dan tanya jawab menunjukkan bahwa peserta yang mencapai hasil cukup 4 orang atau $20 \%$ dan memperoleh hasil baik 12 orang atau $80 \%$ pada aspek identitas program. 2 orang atau $10 \%$ dengan hasil kurang, 5 orang atau $25 \%$ dengan hasil cukup dan 13 orang atau $65 \%$ dengan hasil baik pada aspek materi. Sebanyak 3 orang atau $15 \%$ dengan hasil kurang, 6 orang atau $30 \%$ dengan hasil cukup dan 11 orang atau $65 \%$ dengan hasil baik pada aspek alat dan bahan. Sejumlah 12 orang atau $60 \%$ nilai cukup dan 8 orang dengan nilai baik atau $40 \%$ di bidang kegiatan pembuka. 4 orang atau $20 \%$ dengan hasil kurang, 7 orang atau $35 \%$ dengan hasil cukup dan 9 orang atau $45 \%$ dengan hasil baik pada kegiatan inti. 3 orang atau $15 \%$ dengan hasil kurang, 9 orang atau $45 \%$ dengan hasil cukup dan 8 orang atau $40 \%$ dengan hasil baik pada aspek kegiatan penutup.
9 orang atau $45 \%$ dengan hasil kurang, 9 orang atau $45 \%$ dengan hasil cukup dan 2 orang atau $10 \%$ dengan hasil baik pada aspek rencana penilaian. Hal ini menunjukkan bahwa belum seluruh peserta yang memahami materi penyusunan rencana kegiatan harian yang telah disampaikan yang disampaikan. Oleh karena itu diperlukan adanya pendalaman materi supaya materi yang disampaikan dapat lebih dapat dipahami dan bisa diaplikasikan.

\section{Siklus II}

Siklus dua yaitu sesi ketiga pendalaman materi dan sesi keempat pemberian tugas dan evaluasi. Pendalaman materi dilakukan dengan cara pembimbingan yang lebih mendalam mengenai materi yang disampaikan beserta pemberian contoh dan latihan menyusun rencana kerja harian. Setelah itu peserta diberi tugas dan diadakan evaluasi. Adapun hasil dari pendalaman materi dan pemberian tugas sebagai berikut.

Tabel 4. Hasil penilaian pendalaman materi Penyusunan Rencana Pelaksanaan Pembelajaran Harian II

\begin{tabular}{llccccccc}
\hline No & \multicolumn{1}{c}{ Nama } & $\begin{array}{l}\text { Identitas } \\
\text { Program }\end{array}$ & Materi & $\begin{array}{l}\text { Alat } \\
\text { dan } \\
\text { Bahan }\end{array}$ & $\begin{array}{l}\text { Kegiatan } \\
\text { Pembukaan }\end{array}$ & $\begin{array}{l}\text { Kegiatan } \\
\text { Inti }\end{array}$ & $\begin{array}{l}\text { Kegiatan } \\
\text { Penutup }\end{array}$ & $\begin{array}{l}\text { Rencana } \\
\text { Penilaian }\end{array}$ \\
\hline 1 & Siti Fathonah & 75 & 75 & 69 & 75 & 57 & 65 & 75 \\
2 & Tri Mulianingsih & 60 & 75 & 75 & 67 & 64 & 70 & 75 \\
3 & Istinah & 75 & 75 & 69 & 67 & 54 & 75 & 56 \\
4 & Ris Pratiwi & 75 & 75 & 75 & 75 & 75 & 75 & 75 \\
5 & Santi Ednawati & 65 & 75 & 69 & 58 & 75 & 75 & 75
\end{tabular}


Jurnal Pendidikan Anak, Volume 6, Edisi 1, Juni 2017

\begin{tabular}{|c|c|c|c|c|c|c|c|c|}
\hline 6 & Hanifah & 75 & 75 & 69 & 67 & 75 & 65 & 75 \\
\hline 7 & Sri Supartinah & 75 & 75 & 88 & 83 & 75 & 75 & 63 \\
\hline 8 & Anton Parjuni & 75 & 75 & 75 & 75 & 79 & 75 & 69 \\
\hline 9 & Tutik & 75 & 75 & 75 & 75 & 71 & 65 & 75 \\
\hline 10 & Tumpuk & 75 & 75 & 75 & 75 & 75 & 75 & 75 \\
\hline 11 & Muji L & 60 & 69 & 69 & 67 & 75 & 75 & 75 \\
\hline 12 & Okta & 75 & 75 & 69 & 75 & 68 & 60 & 69 \\
\hline 13 & Sumiyatun & 75 & 75 & 75 & 75 & 68 & 70 & 63 \\
\hline 14 & Trina & 75 & 69 & 75 & 75 & 71 & 60 & 75 \\
\hline 15 & Tumini & 65 & 69 & 75 & 75 & 71 & 65 & 69 \\
\hline 16 & Surti Darti & 75 & 69 & 75 & 67 & 64 & 70 & 63 \\
\hline 17 & Siti Maslikhah & 75 & 75 & 69 & 67 & 61 & 75 & 69 \\
\hline 18 & Iskamtiyati & 75 & 75 & 75 & 67 & 75 & 75 & 56 \\
\hline 19 & Ngatirah & 70 & 75 & 75 & 75 & 75 & 75 & 81 \\
\hline 20 & Ani Rubia Bekti & 75 & 75 & 75 & 75 & 71 & 75 & 75 \\
\hline
\end{tabular}

Skor maksimal

$\begin{array}{ll}\text { Ketercapaian: } 86 \%-100 \% & \text { : Sangat baik } \\ 70 \%-85 \% & \text { : Baik } \\ 55 \%-69 \% & : \text { Cukup } \\ \text { Dibawah } 55 \% & \text { : kurang }\end{array}$

Hasil yang diperoleh dari siklus dua yaitu sesi ketiga pendalaman materi menunjukkan bahwa peserta yang mencapai peserta yang mencapai hasil cukup 4 orang atau $20 \%$ dan memperoleh hasil baik 12 orang atau $80 \%$ pada aspek identitas program. 4 orang atau $20 \%$ dan memperoleh hasil baik 12 orang atau $80 \%$ pada aspek materi. Sebanyak 7 orang atau $35 \%$ dengan hasil cukup dan 13 orang atau $65 \%$ dengan hasil baik pada aspek alat dan bahan. Sejumlah 8 orang atau $40 \%$ nilai cukup dan 12 orang dengan nilai baik atau $60 \%$ di bidang kegiatan pembuka. Sebanyak 7 orang atau $35 \%$ dengan hasil

cukup dan 13 orang atau $65 \%$ dengan hasil baik pada kegiatan inti. Sebanyak 6 orang atau 30\% dengan hasil cukup dan 14 orang atau $70 \%$ dengan hasil baik pada pada aspek kegiatan penutup. 9 orang atau $45 \%$ dengan hasil cukup dan 11 orang atau 55\% dengan hasil baik pada aspek rencana penilaian. Hal ini menunjukkan bahwa terdapat peningkatan pemahaman mengenai materi yang disampaikan. Peserta dapat memahami materi yang disampaikan dengan lebih baik dan dapat menyusun rencana kerja harian melalui pemberian tugas serta evaluasi.

Tabel 5. Hasil Evaluasi

\begin{tabular}{clccccccc}
\hline No Nama & $\begin{array}{c}\text { Identitas } \\
\text { Program }\end{array}$ & Materi & $\begin{array}{l}\text { Alat } \\
\text { dan } \\
\text { Bahan }\end{array}$ & $\begin{array}{l}\text { Kegiatan } \\
\text { Pembukaan }\end{array}$ & $\begin{array}{l}\text { Kegiatan } \\
\text { Inti }\end{array}$ & $\begin{array}{l}\text { Kegiatan } \\
\text { Penutup }\end{array}$ & $\begin{array}{l}\text { Rencana } \\
\text { Penilaian }\end{array}$ \\
\hline 1 & Siti Fathonah & 85 & 81 & 75 & 75 & 93 & 85 & 94 \\
2 & Tri Mulianingsih & 85 & 88 & 69 & 75 & 93 & 90 & 94 \\
3 & Istinah & 80 & 88 & 75 & 75 & 89 & 90 & 94 \\
4 & Ris Pratiwi & 85 & 88 & 75 & 83 & 93 & 90 & 88 \\
5 & Santi Ednawati & 85 & 94 & 75 & 83 & 93 & 90 & 88 \\
6 & Hanifah & 85 & 94 & 75 & 83 & 93 & 95 & 88 \\
7 & Sri Supartinah & 90 & 94 & 88 & 83 & 86 & 85 & 94 \\
8 & Anton Parjuni & 90 & 94 & 88 & 75 & 86 & 90 & 94 \\
9 & Tutik & 90 & 94 & 94 & 75 & 75 & 90 & 81 \\
10 & Tumpuk & 80 & 94 & 94 & 83 & 86 & 90 & 88 \\
11 & Muji L & 80 & 94 & 88 & 75 & 82 & 85 & 81 \\
12 & Okta & 85 & 81 & 88 & 92 & 79 & 75 & 94 \\
13 & Sumiyatun & 80 & 100 & 88 & 92 & 89 & 85 & 81 \\
14 & Trina & 85 & 100 & 88 & 75 & 86 & 90 & 88 \\
15 & Tumini & 75 & 88 & 69 & 75 & 79 & 75 & 88
\end{tabular}


Jurnal Pendidikan Anak, Volume 6, Edisi 1, Juni 2017

\begin{tabular}{llccccccc}
16 & Surti Darti & 80 & 81 & 75 & 83 & 82 & 90 & 81 \\
17 & Siti Maslikhah & 85 & 100 & 88 & 92 & 89 & 85 & 75 \\
18 & Iskamtiyati & 85 & 81 & 88 & 83 & 82 & 90 & 75 \\
19 & Ngatirah & 100 & 100 & 75 & 100 & 82 & 80 & 75 \\
20 & Ani Rubia Bekti & 95 & 100 & 81 & 75 & 71 & 75 & 81 \\
\hline
\end{tabular}

Hasil yang diperoleh dari siklus dua yaitu sesi keempat pemberian tugas dan evaluasi menunjukkan bahwa peserta yang mencapai peserta yang mencapai hasil baik 15 orang atau $75 \%$ dan memperoleh hasil sangat baik 5 orang atau $25 \%$ pada aspek identitas program. Sebanyak 4 orang atau $20 \%$ dengan hasil baik dan 16 orang atau $80 \%$ dengan hasil sangat baik pada aspek materi. 2 orang atau $10 \%$ dengan hasil cukup, 8 orang atau $400 \%$ dan memperoleh hasil baik dan 10 orang atau $50 \%$ dengan hasil sangat baik pada aspek alat dan bahan. Sejumlah 14 orang atau $70 \%$ nilai baik dan 6 orang dengan nilai sangat baik atau $30 \%$ di bidang kegiatan pembuka. Sebanyak 7 orang atau $35 \%$ dengan hasil baik dan 13 orang atau $65 \%$ dengan hasil sangat baik pada kegiatan inti. 9 orang atau $45 \%$ dengan hasil baik dan 11 orang atau 55\% dengan hasil sangat baik pada aspek kegiatan penutup. Sebanyak 8 orang atau $40 \%$ dengan hasil baik dan 12 orang atau $60 \%$ dengan hasil sangat baik pada aspek rencana penilaian.

\section{PEMBAHASAN}

Kondisi awal menunjukkan bahwa pemberian materi mengenai penyusunan rencana kegiatan harian merupakan hal baru bagi rata-rata peserta. Hal ini ditunjukkan dengan adanya beberapa peserta yang masih belum memahami materi dan disampaikan dan masih terdapat kesulitan untuk menyusun rencana kegiatan harian. Hal ini disebabkan berbagai faktor antara lain perbedaan usia guru dan kepala sekolah, perbedaan tingkat pendidikan dan perbedaan tingkat kompetensi.

Dengan memperhatikan kondisi tersebut sebagai metode refleksi, pengawas memberikan pendalaman materi mengenai penyusunan rencana kegiatan harian dengan cara memberikan penjelasan lebih mendetail dengan bahasa yang lebih mudah dimengerti, memberikan contoh laporan yang sudah jadi, mengadakan sesi tanya jawab dan latihan. Setelah itu pengawas mengadakan evaluasi dengan tujuan mengetahui tingkat pemahaman materi terhadap peserta. Hasil menunjukkan bahwa terdapat peningkatan mengenai pemahaman materi dengan naiknya skor nilai peserta. Hasil ini didapat dari evaluasi pemberian tugas yaitu latihan penyusunan rencana pelaksanaan pembelajaran harian.

Pendampingan dilaksanakan dengan pemberian materi melalui tahap pengenalan, pemberian contoh, pendalaman serta pemberian tugas dengan tujuan membuat guru dan kepala TK mengetahui, mengerti dan memahami materi mengenai penyusunan rencana pelaksanaan pembelajaran harian. Adapun metode yang paling efektif adalah dengan cara pengulangan serta pemberian tugas dengan harapan guru dan kepala TK akan terbiasa dengan topik yang dibahas serta mampu untuk menyusun karena telah mendapatkan contoh serta latihan.

Pendampingan lebih lanjut adalah dengan menerapkan rencana pelaksanaan pembelajaran harian pada KTSP sekolah yang telah disusun sembari mengobservasi dan mengevaluasi guna mencari metode mana yang terbaik bagi proses pembelajaran melalui supervisi akademik lebih lanjut. Penyusunan rencana kegiatan harian tentunya disesuaikan dengan tema berdasarkan KTSP dan peserta didik.

\section{PENUTUP}

Pembimbingan penyusunan rencana kegiatan harian dapat meningkatkan kemampuan guru dalam menyusun rencana kegiatan harian menunjukkan bahwa peserta yang mencapai hasil baik. Hasil yang diperoleh dari siklus satu yaitu 
sesi pemberian materi dan sesi latihan penyusunan rencana cukup sebanyak 16 orang atau $80 \%$ dan dengan hasil baik sebanyak 4 orang atau $20 \%$.

Hasil yang diperoleh dari siklus dua yaitu sesi ketiga pendalaman materi dan sesi keempat pemberian tugas dan evaluasi menunjukkan bahwa peserta yang mencapai hasil cukup sebanyak 4 orang atau $20 \%$ dan dengan hasil baik sebanyak 16 orang atau $80 \%$ pada siklus 3 dan 20 orang dengan hasil baik atau $100 \%$. Hal ini menunjukkan bahwa terdapat peningkatan pemahaman mengenai materi yang disampaikan. Peserta dapat memahami materi yang disampaikan dengan lebih baik dan dapat menyusun rencana kerja harian berbasis budaya melalui pemberian tugas serta evaluasi.

Dari hasil penelitian maka peneliti memberikan saran untuk :

\section{Kepala sekolah}

Mempertahankan dan meningkatkan kerjasama dan koordinasi dengan guru dalam penyusunan rencana kegiatan harian berbasis budaya. Berperan aktif dalam menciptakan iklim kondusif di lingkungan sekolah.

\section{Guru}

Meningkatkan pemahaman dan tanggung jawab terhadap proses pembelajaran sehubungan dengan penyusunan rencana kegiatan harian berbasis budaya. Mengimplementasikan rencana kegiatan harian berbasis budaya yang telah disusun dalam proses pembelajaran.

\section{DAFTAR PUSTAKA}

Abdullah I. (2006). Konstruksi dan Reproduksi Kebudayaan. Yogyakarta : Pustaka Pelajar.

Buku kerja pengawas pusat pengembangan tenaga kependidikan badan pengembangan sumber daya manusia pendidikan dan penjamin mutu pendidikan kementerian pendidikan nasional tahun 2011
Koentjaraningrat. (2000). Pengantar Ilmu Antropologi. Jakarta : Radar Jaya Offset.

Pedoman Pelaksanaan Pendidikan Berbasis Budaya Di TK. (2014). dinas pendidikan pemuda dan olahraga daerah istimewa yogyakarta 2014. http// seputar pengetahuan

Peraturan Gubernur Daerah Istimewa Yogyakarta Nomor 66 tahun 2013 tentang kurikulum berbasis budaya

Peraturan Gubernur Daerah Istimewa Yogyakarta Nomor 68 Tahun 2012 tentang pedoman penerapan nilai nilai luhur budaya dalam pengelolaan dan penyelenggaraan pendidikan

Peraturan daerah propinsi Daerah Istimewa Yogyakarta nomor 4 tahun 2011 tentang tata nilai budaya Yogyakarta

Perda DIY Nomor 5 Tahun 2011 berisi tentang pengelolaan dan penyelenggaraan pendidikanberbasis budaya

Peraturan Pemerintah Nomor 46 tentang sasaran kinerja pegawai 2011

Permendiknas No mor 58 tahun 2009 tentang standar pendidikan anak usia dini ( paud). http// id.tesis.com

Setiadi, Elly M, dkk. (2006). Ilmu Sosial dan Budaya Dasar. Jakarta : Kencana. 